\title{
Consumer Protection and the Regulation of Mobile Phone Contracts: A Study of Automatically Renewable Long-Term Contracts Across Jurisdictions
}

\author{
C. Bisping ${ }^{1}$ (D) T. J. Dodsworth ${ }^{2}$
}

Received: 18 December 2018 / Accepted: 9 April 2019 / Published online: 14 June 2019

(C) The Author(s) 2019

\begin{abstract}
This article deconstructs mobile phone contracts as an example of long-term contractual relations in four jurisdictions to reveal that there are three elements which define consumer protection. The elements are contract duration, renewal of the agreement and unilateral modification. Each of these factors are regulated differently in each of the jurisdictions, but, assessed collectively, similar levels of consumer protection are found. The authors show that the reason for the different weighting is determined by regulation (subject-specific or general); by external factors, such as technological development, geography or business considerations; and by wider cultural considerations. The comparison of these features across the jurisdictions shows that, ultimately, regulatory intervention plays little role in contract design, unless an overwhelming policy goal is pursued, which means that, in most cases, regulators would be advised to avoid or reduce regulation of mobile phone and other long-term contracts.
\end{abstract}

Keywords Contract law · Comparative law $\cdot$ Long-term contracts $\cdot$ Regulation · Harmonization · Consumer protection

The evolution of technology and corresponding changes in consumer behaviour (Bar-Gill and Stone 2012, p. 430) have led to mobile phones becoming a necessary and indeed central part of modern private and business life. Despite their ubiquity, mobile phone contracts have attracted

The authors would like to thank Prof Hugh Beale, Prof Rebecca Probert, Prof Andrea Lista, Dr Severine Saintier and Peter Tyldesley for their invaluable comments on earlier drafts and Zaina Mahmoud for her editorial work. Both authors' contributions to this article are equal. All errors remain our own.

C. Bisping

c.bisping@warwick.ac.uk

T. J. Dodsworth

t.j.dodsworth@exeter.ac.uk

1 School of Law, University of Warwick, Coventry CV4 7AL, UK

2 School of Law, University of Exeter, Amory Building Rennes Drive, Exeter EX4 4RJ, UK 
relatively little scholarly attention, exceptions are Bar-Gill and Stone (2012) and Bar-Gill (2012 p. 185). They provide a useful case study of the legal regulation of long-term contracts more generally. While business models and economic structures move away from one-off transactions to long-term relations, as expressed in the advent of the so-called sharing economy or 'subscription economy' (McKinsey 2018), a heavily regulated type of contract, such as those for mobile phones, will serve as a model for insights that apply equally to other types of long-term contractual relationships. This is even more poignant as many of the sharing and subscription business models are driven by mobile telephony.

This article will focus on the three features that characterize mobile phone, and other longterm, contracts the most: the duration of the contract, i.e., the initial commitment period, the ability to automatically renew the contract at the end of the initial term, and the possibility of unilateral modification of the contract by the service provider. It will do so by comparing the solutions applied in four jurisdictions - Germany, the United Kingdom, the United States (US) and $\mathrm{Canada}^{1}$ - which provide examples of different approaches to the regulation of mobile phone contracts and illustrate differing attitudes to long-term contracts. ${ }^{2}$ However, it will not attempt to provide an analysis of every aspect of the customer-provider relationship in longterm contracts, and will not address questions of wider contract and consumer law, such as remedies for breach and contracting mechanisms more generally.

It will be argued that the features which are the focus of analysis are characteristic for mobile phone, and other long-term contracts which indicate whether a system of law favours consumer or business interests. It will be shown that the balance struck between these three features depends on the wider policies pursued by the legislator. A policy that forms part of the legislators' concerns across all jurisdictions is the competitiveness of markets as a way to protecting consumers' interests. It will be shown that regulating the contractual framework of mobile phone and other long-term contracts does not have the effect of creating a competitive market. Regulation of the crucial aspects - initial term, renewal and unilateral modification - can discourage competitors from entering the market since it is less attractive to join a heavily regulated market than a less regulated market. The effects of such regulation are therefore likely to lead to either price increases or reduced competition, unless they are compensated internally by relaxing regulation of another key factor.

\section{General Characteristics of Long-Term Mobile Phone Contracts}

Mobile phone penetration is at or above $100 \%$ in many Western countries, with around $70 \%$ of consumers having access to a smartphone. In those countries, mobile phone use is mainly facilitated by post-paid contracts between users and providers, which are subject to varying levels of regulation in different jurisdictions despite some having a common framework (in Directive 2018/1972/EU establishing the European Electronic Communications Code; in Canada Telecom Regulatory Policy, 2013/271/CA). In developing countries, the market looks often rather different and most consumers use mobile phones on a pay-as-you-go basis; in

\footnotetext{
${ }^{1}$ The jurisdictions were chosen as representatives of the varying approaches to long-term contracts which outlined in another study; see Dodsworth et al., 2014.

2 This comparison will be methodologically based on functional equivalents (Zweigert and Kötz 1998), which means that although this paper will outline the approach taken by courts of the varying jurisdictions, relying on structural (functional) comparison (Weir 1992, p. 1616), the focus will be on the conclusion arrived at (Samuel 2014, pp. 17-18), and therefore, no suggestions will be made about which system may offer the 'better' solution (see on the topic of legal transplants, Legrand 1997).
} 
some parts of Africa, for example, mobile phones serve the additional function of providing financial services to the 'unbanked and under-banked' local population (Malala 2018, p. 363). This article will focus on the first situation, long-term post-paid agreements; as to the alternative situation, see the papers in the Journal of Consumer Policy (JCP) Special Issue on Consumer Law in Africa (2018, issue 4).

Long-term contracts are primarily identified and characterized by the obligations the parties assume, and are entitled to expect, under them. For mobile phone contracts, these are the price and the basket of goods and services provided in exchange. Typically, a mobile phone contract will include a number of telephony minutes, text messages and a volume of data as part of the monthly subscription price; additional usage is to be paid for on a use basis. Often, the package included the provision of a handset. This bargain that the parties have struck is beyond the analysis of this article. It is often beyond the reach of the law in any case as the adequacy of the bargain is typically not subject to legal control; such core terms are, e.g. exempt from the assessment for fairness under the European Unfair Contract Terms Directive (Dir 93/13/EEC, Art. 4(2)). This article will analyse instead those features that are most likely to have the greatest influence on the commercial bargain: the initial commitment period, the mechanism of renewal on expiry of the initial term and the possibility to unilaterally alter the term.

At the same time, pricing is one of the most important aspect in consumer's decisionmaking when choosing mobile phone contracts. Existing research has focused on the complexity of pricing structures which are likely to confuse customers (for more information on behavioural economics in relation to consumers, see Lunn 2013 and Bar-Gill 2012). One innovative pricing technique, found in some countries, is the partial unbundling of telephony services from the sale of handsets in order to avoid cumbersome aspects of regulation. Handsets are sold on 36-month credit agreements that are coupled to a 24-month mobile telephony contract. This set-up allows providers to overcome the maximum contract length of 24 months that exists in some countries. This set-up, on the other hand, addresses a concern in the more traditional bundled version of contracting where some consumers continue to pay for a subsidized handset after the expiry of the initial commitment period, despite the cost of the handset being fully amortized (Ofcom 2018). As these aspects do not concern the long-term contract as such, they are beyond the scope of this article.

The identification of these three aspects somewhat resembles the division in duration, economy and terms suggested by Bell (1989) as key concerns in long-term contracts. Each of these features will be examined in turn, with particular attention paid to the way in which the degree and nature of regulation is influenced by policy considerations as expressed in industry-specific regulation and the general law, as well as by external factors, such as technological developments, geography and business influences. Other factors that might have an impact on long-term mobile phone contracts, such as broader cultural preferences, will not be discussed here. An example of such factors is the openness of the market for foreign service providers (Standing Committee on Industry Science and Technology 2010). In this sense, culture refers to certain long-held and deeply ingrained preferences shared within a legal system. Some of those phenomena will be encountered later, such as the attitude of German law that parties to a long-term contract must strictly comply with notice periods, without a reminder to that effect, or the emphasis placed on one-off transactions which has led to a level of hostility to long-term commitments. The reasons for those preferences and a more thorough analysis of them are outside the scope of this paper. 
That is not to say that initial duration, renewal and unilateral modification are the only features of contract law that determine the level of consumer protection. Other aspects of contract law, such as inter alia the availability of, and pre-requisites for the exercise of, remedies, or withdrawal rights during a cooling-off period, and other branches of law, in particular trading standards and access to dispute resolution mechanisms, are equally important for the level of consumer protection found within a system. These areas are not specific to long-term contracts, as exemplified by mobile phone contracts, though and will therefore not be further discussed. It will be noted though that some systems under discussion heavily rely on general contract law, whereas others provide sector-specific regulation. The internal positioning of the rules is of no significance for the determination of the overall level of consumer protection.

\section{Initial Commitment Period}

There are two prototypes of mobile phone contracts. First, the prepaid or monthly rolling contracts, where the customer either pre-pays or post-pays for a service on a monthly basis without commitment beyond one month. Second, contracts with a predetermined initial commitment period of over one month, where the customer will pay a set fee for at least the number of months set out in the contract term. This article will focus solely on the second type as a long-term commitment. Contracts of that type in turn can include the provision of a handset, or they can be SIM-only, i.e., limited to the provision of telephony services without the necessary hardware. The following analysis is based on the assumption that the majority of mobile phone contracts include the provision of handsets and are designed to attract customers by making the expensive handset more affordable. Most of the findings apply equally to SIM-only contracts though.

The mobile phone user, when entering into the agreement, will consider the length of time that they will be bound by the contract, not only in order to compare market rates but also to make the (usually costly) handset affordable by being able to pay for it in instalments (Bar-Gill and Stone 2012). Mobile phone providers have a substantial interest in binding customers for a certain length of time to amortize the cost of the handset (Bar-Gill 2012, p. 207). They can also attract new business by allowing the customer to spread the cost of the handset over a period of time, making the contract seem more affordable (Bar-Gill 2012, pp. 223-231). We will see later though, that there are disadvantages for service providers when the provision of the services becomes costlier, which is why they may want to modify the price, either during the initial commitment period or upon renewal.

The options for initial commitment periods for mobile phone contracts have changed over time (Dodsworth et al. 2014). In the past, mobile phone providers offered a whole range of options, from one-month rolling contracts to contracts for 12, 18, 24 and even 36 months. Today, however, 24-month contracts dominate the market in all the jurisdictions under consideration (Bar-Gill and Ben-Shahar 2013). To the extent that this represents a change in practice, it has come about through a combination of regulatory intervention, business influences, technology and culture. In order to establish the regulatory context within which this article will consider these influences, it is necessary to consider the national rules of each jurisdiction. 


\section{The Law}

In Europe, the length of mobile phone contracts is determined not only by national laws but also by the regulatory framework laid down by the European Union. The EU has recognized the importance of the telecommunications sector as an essential element in furthering the internal market. In 2002, it established the Telecommunications Framework Directive, which was then followed by the 'EU Telecoms Package' in 2009 (Regulation (EC) No 1211/2009; Directive 2009/136/EC; Directive 2009/140/EC; Telecom Regulatory Policy 2013), with the aim of harmonizing the market on telecommunication services. The legal basis for the package is the achievement of the internal market according to Articles 26 and 114 TFEU; the first EU measure in this sector (Directive 1988/301/EEC on Competition in the Markets in Telecommunications Terminal Equipment) was enacted to increase competition in the then predominantly landline telecoms market. As with the later measures, the tool of competition is used to support the aim of creating the internal market (Dir 1988/301/EEC rec. 3). The 2009 EU Telecoms Package introduced a maximum initial commitment period of 24 months and the obligation to offer a 12-month tariff (Directive 2009/136/EC, Art. 30(5)). The maximum length of 24 months is now enshrined in the European Electronic Communications Code (Directive 2018/1972/EU, Art. 105), which has given up the requirement for a 12 month variant. In the UK, the maximum length for mobile phone contracts had not previously been regulated by specific legislation and the national regulator - OFCOM - had not taken any action to reduce the initial commitment period. Ofcom had taken steps to restrict the automatic renewal of contracts though (Ofcom 2013a, b). It was therefore common to find 36-month contracts, although these only ever accounted for a minority of the market. The majority ( $80 \%$ ) of UK mobile phone contracts prior to the 2009 Directive, in fact, had a length of 18 months. This has now changed dramatically. Twenty-four-month contracts now account for two thirds of the UK market, and the last third is split more or less equally between one-month rolling contracts and 12-month contracts (Ofcom 2013a, pp. 1-162). The previously popular 18month contracts have now almost entirely disappeared, accounting for only $2 \%$ of the market. While it should be acknowledged that technological developments have contributed to this development, regulatory intervention has had a clear economic impact, with the majority of contracts shifting towards the upper permissible limit. The shift will be examined below but suffice it to say at this stage that the number of 18-month contracts dropped by half within six months of a change in legislation.

A different shift can be observed in Canada where the desire was, rather than harmonisation, to make the market more competitive. In 2012, the Canadian RadioTelevision and Telecommunications Commission (CRTC) began a public consultation to establish a mandatory code for cellular wireless services (Telecom Regulatory Policy 2013), which resulted in the CRTC Wireless Code. The consultation was sparked after a parliamentary committee had concluded that the progress of broadband penetration in Canada was 'disappointing' (Middleton 2011, p. 69.5). Overall, it was therefore accepted that the telecommunications sector should be reviewed, coupled with a particular recommendation that steps should be taken to introduce more competition in the market (Middleton 2011, p. 69.9). As a measure to improve competitiveness, the CRTC Wireless Code introduced a maximum initial commitment period of 24 months (Telecom Regulatory Policy 2013, para. 220). Before the introduction of the Wireless Code, mobile phone contracts in Canada typically had an initial commitment period of 36 months (CBC News 2012), which was considered to be contrary to consumers' interests, due to the fact that handsets were often out of date before the initial 
commitment period had ended. However, an effect of the introduction of the Wireless Code and the shortening of contracts to 24 months has been a stagnation of the contract price; this is in contrast to most other countries where typical contract prices have continuously fallen (NGL Nordicity Group Ltd. 2017, p. 29, fig. 3; OECD 2011).

In contrast to the Canadian and English approaches, mobile phone contracts in Germany are primarily regulated by general contract law rather than by industry-specific regulations. The industry regulator, the federal network agency (Bundesnetzagentur), lays down rules on contracting to a very limited extent only in the Transparenz Verordnung 2016 Section 5, and predominantly deals with technical aspects of the telecommunications services. The regulation of the initial commitment period is mostly determined by the general provisions on unfair contract terms in consumer contracts. Section 309 No. 9 (a) BGB limits the initial commitment period of any long-term consumer contract entered into based on the trader's standard terms of contracting to 24 months. A term providing for a duration of more than 24 months in any such consumer contract would be considered unfair and thus void. The EU Telecoms Package that affected the English maximum initial commitment period had little influence on the German approach, because the initial commitment period for most contracts was already limited to 24 months under general contract law (BGB Section 309(9)(a)). In the sector-specific legislation, Section 43b TKG reiterates the maximum of 24 months and extends it further to individually negotiated contracts and to contracts entered into by small traders, who would not be regarded as consumers as they are not dealing for private consumptive purposes. These extensions highlight the very limited scope of application of Section $43 \mathrm{~b}$ as it is unlikely that mobile phone contracts are based on anything other than the provider's standard terms of contracting; the provision in the explanatory notes on the bill is therefore referred to solely as 'avoiding deficient implementation' (Bundesregierung 2011, p. 65). Section 43b TKG further provides that providers must offer a 12-month tariff as it serves to implement Directive 2009/136/EC, Art. 30(5), which is described as a measure to further improve competition (Bundesregierung 2011, p. 65).

In the US, the Federal Communications Commission deals with, inter alia, mobile phones, but does not extend its activities to the contractual arrangements between consumers and the provider. The regulation of the terms and conditions of mobile phone contracts therefore falls to the individual states. There is a federal prohibition on the regulation of rates but an express authorization to make provisions for the regulation of 'other terms and conditions'. (47 US Code 2012, Section 332(c) (3) (A)). Despite several attempts at both state (Public Utilities Commission of the State of California 2006; MA S1617 2013; Minnesota Statutes 2004 Section 325F.695; for New York see Chang 2012; some form of mobile phone consumer protection has been discussed by the legislators of 22 states, see Ante 2008) and federal (Cell Phone User Bill of Rights, S. 1216, 108th Cong 2003) levels, no 'mobile phone users bill of rights' has so far been successfully established. There is no nationwide data available as to the initial commitment period of mobile phone contracts; in practice, by far the most common are 24-month contracts (O'Grady 2008; a legislative overview is given by Bar-Gill 2012 pp. 239240).

This overview suggests that legislative regulation can affect the initial commitment period in two ways. The most obvious effect is when it limits the length of the contract, where previously most contracts were longer than the new imposed maximum length. In those cases, the providers will (necessarily) shorten the length of the initial commitment period with the consequence of a rise in the monthly subscription cost, as has occurred in Canada. 
However, the second scenario relates to cases where a maximum initial commitment period is imposed where previously the market was relatively diverse, as in the case of the UK. It would appear that where the regulator imposes a maximum limit on the initial commitment period, the market moves towards the new maximum (permissible) limit (Cooter and Ulen 2012, pp. 32-33). Atamer (2017 p. 641) points to the move towards the maximum permissible in case of the levy of $£ 12$ default fees for credit cards after the former UK Office of Fair Trading set this as the threshold to unfairness. For mobile phone contracts, this has the effect of severely diminishing the mid-range market (i.e., 12- and 18-month contracts). The claim that limiting the contract term to 24 months can 'balance the interests of both parties' (Atamer 2017, p. 648) seems therefore not always correct. It is not suggested here that legislative intervention is the only explanation for the change in the market, but it is argued that it is a significant factor, as the three examples of Germany, the UK and Canada have shown that in systems that prescribe a maximum contract length, the market tends to move towards making use of the maximum, at the expense of other options. Only in the US was a de facto two-year limitation settled on without regulatory intervention. Under some of the proposed mobile phone users' bills of rights, the contract duration would have been regulated (e.g., MA S1617 2013-2014, S 120A).

\section{Business Influences}

Alongside the initial commitment period, the other key consideration for mobile phone users is the monthly cost of the contract. A lower monthly cost may incentivize consumers to enter into longer-term contracts. Similarly, if more customers enter into longer contracts (for example where the market changed, as in the UK), then this might in turn reduce the monthly cost of the contract, since service providers would have more certainty as to their income over a longer period.

The term "business influences" in this section refers to the influence of a change in the maximum initial commitment period on the cost of the overall contract, taking into account the overall fall in contract prices for the same time period in countries which introduced no change in the initial commitment period. As shown above, the 2009 EU Telecoms Package, which introduced a maximum term of 24 months (now Directive 2018/1972/EU, Art. 105(1)), had an effect on UK consumers, as most mobile phone contracts used to be for a maximum period of 12 or 18 months (Ofcom 2013a). The Directive seems to have almost eradicated 18-month contracts (a fall from $63 \%$ in the last quarter of 2008 to $24 \%$ by the first quarter of 2010 and only $3 \%$ by the first quarter of 2011) in favour of 24-month contracts (a rise from $7 \%$ in the last quarter of 2008 , to $50 \%$ by the first quarter of 2010 and $68 \%$ in the first quarter of 2011) (Ofcom 2013a). But this is only part of the picture, as, in turn, the average monthly cost of a contract in the UK has decreased. While in the last quarter of $200855 \%$ of contracts cost $£ 30$ or more per month, by the first quarter of 2010 , only $39 \%$ were in that price bracket, and by the first quarter of 2011, it was only $28 \%$; at the same time, the proportion of contracts costing less than $£ 30$ per month increased correspondingly (Ofcom 2013a, 2013b, p. 96).

The reverse trend can be found in Canada. As discussed above, the majority of contracts used to have an initial commitment period of 36 months (CBC News 2013), which was lowered due to the CRTC requirement of a maximum 24-month initial commitment period (Telecom Regulatory Policy 2013, para. 220). This also affected the price. Prices for consumers with lower than average consumption rose by roughly $16 \%$ after the introduction of the 
Wireless Code (Wall Communications Inc. 2014). However, for average consumption users, the cost remained steady between 2013 and 2014, and higher than average consumption contracts (i.e., CAN $\$ 80$ and above) dropped from an average price of CAN\$93 in 2013 to CAN\$80 in 2014 (Wall Communications Inc. 2014).

Prices for mobile phone services have continually fallen in Germany too, by $2.3-3.5 \%$ per year between 2007 and 2012 (Statistisches Bundesamt 2017). What this means in absolute terms can be illustrated by comparing OECD (2011) and OECD (2013), with a snapshot of the prices in August 2010 and August 2012, where the price fell for a bundle of 100 calls from US\$42.63 to US\$30.88.

It would appear, therefore, that the market in the UK behaved in the expected manner, and that because the market moved towards longer 24-month contracts, the cost per month was reduced, resulting in a static total cost over the duration of the contract. Price decreases in Canada (for some contract types) and Germany suggest a different picture though: Here, prices dropped even in circumstances of shorter, or unchanged, contract terms, suggesting a general drop in prices for wireless telephone services due to a more saturated, mature and established market (OECD 2011).

\section{Technology}

One of the factors that influences consumers' behaviour is the technology that is often linked to the mobile phone contract. The mobile phone, as a means of communication, has seen a remarkable transformation in terms of consumer usage, as well as technological advancement. Mobile phones are being used more often, and for different purposes, such as mobile browsing (Nielson Company 2013). A long contract duration, such as the 36month contracts that dominated the market in Canada, might have rendered devices obsolete before the end of the contract term due to the outdated hardware (Telecom Regulatory Policy 2013 para 216). It is clear that the change in usage occurred when there was a shift from feature phones (no touchscreen) to smartphones (touchscreen and use of apps) (Nielson Company 2013 p. 9). Consumers therefore needed to strike a balance between the desire to keep up with the latest technology (i.e., frequent changing of the handset) and the increased price of the handsets. Prior to the release of the first iPhone, the cost of mobile phones (e.g., Motorola Razr, Blackberry Pearl) had dropped to an all-time low (Timetoast 2015). The release of the first iPhone meant that consumers were faced with an increase in the cost for their handset, which is likely to have influenced them to enter into contracts with a longer initial commitment period in order to spread the cost over a longer period.

In the first year of the release of the iPhone, the number of 18-month contracts (the once dominant length) fell in the UK, with a large increase in one-month contracts and a slight increase in 24-month contracts (Ofcom 2013a, 2013b). The increase in one-month contracts is likely to be due to the fact that consumers decided to buy the iPhone without a service provider's subsidy and then added the mobile phone contract. The consistent rise in the popularity of 24-month contracts indicates that consumers have since opted to spread the cost of the handset over a longer period.

This supports the suggestion that the increase in the cost of the mobile phones through the introduction of smartphones has contributed to the increase of the initial commitment period. It 
is assumed that the trend of mobile phone replacement cycle is similar in the UK and Canada, where the contract does not automatically renew, and the consumer remains on the same tariff.

A further factor influencing price is the investment in the infrastructure required from mobile phone operators. However, the assumption based on the general trends shown in the Organisation for Economic Co-operation and Development (OECD) international comparison (OECD 2011) must be that the level of investment in the infrastructure, though not the same in amount, must have been the same from one year to the next. We would also expect the investment to increase (in terms of percentage) in the same way across each of the jurisdictions when new technologies, such as $4 \mathrm{G}$, were introduced. A related issue is the cost of spectrum which differs between jurisdictions but is an expression of the move towards private management of public airwaves. These elements therefore are not taken into account in our assessment.

A further factor that influences the cost and could therefore have an impact on the length of the contract is the geography of a country. In Canada, it is accepted that the running of the network is more expensive due to the vast geographical space the network providers must cover. In the UK, the space is comparatively small. It could therefore be argued that the higher overall cost of operating the network has an impact on the demand for longer-term contracts. In other words, the higher overall cost of running the network in Canada means that consumer demand is significantly lower (due to high overall cost of the contract itself) than in the UK. However, this must be doubted on the basis that the highest charges were recorded in Germany, which is far more densely populated than Canada, but less than the UK, with a maximum length of 24 months. Also, it would seem from the above statistics that there has not been a significant increase in the monthly cost of the contract in Canada after the introduction of a 24-month maximum initial commitment period. It is therefore argued here that although the providers claimed (Middleton 2011) that the geography is responsible for the high cost and so justified the fact that they only offered 36-month contracts, it was in fact the lack of competition which led to the high initial commitment period (Telecom Regulatory Policy 2013, para 202). This is partly substantiated by the fact that in some cases the consumer may not even be aware that a provider belongs to a larger telecommunications network (Chu 2009). In the other countries discussed here, lack of competition does not appear to be a major factor as there are three or four operators with a market share of more than 10\% (UK: BT 2018; Germany: VATM 2018; USA: FierceWireless 2018).

\section{Renewal}

Another factor influencing long-term contractual relationships is the possibility of bringing the agreement to an end or, alternatively, the option of preventing its expiry by renewing it. While the initial commitment period of the contract is a primary concern for consumers when entering into a mobile phone contract, the fate of the agreement at the expiry of the initial period is of key importance for the provider. Even if the initial period is fairly short, an automatic renewal by the same term burdens the consumer, who might not have considered such an automatic extension, while at the same time benefitting the service provider, who retains a customer for another fixed term. Renewal on unchanged terms might constitute a disadvantage for the provider though if it cannot adapt the contract price to price increases or other changed circumstances (see below, for the provider's possibilities to unilaterally modify contract terms). A related issue is the ability of a user to terminate the agreement before the expiry of the initial term, and what this might cost. 
Provisions in long-term contracts relating to their expiry are designed in different ways. Contracts can be entered into for an undefined period of time, giving the parties the right to terminate the agreement by giving notice. Contracts can also be entered into for a fixed term, ending automatically on expiry of the term. Fixed-term contracts, rather than coming to an end, might be automatically renewed for the same, or another defined, term. In the utilities sector, contracts tend to extend for an indefinite period via the standard variable rate, though this may not be the most efficient for consumers (Bisping and Dodsworth 2017). There are benefits for both parties to such a practice: In return for accepting a renewable long-term commitment, the customer might get a lower price than they would have been able to obtain in a one-off or short-term transaction. It might also be in the consumer's interest to have a continuous supply of goods or services without the necessity of having to look for alternative means of supply. In mobile phone contracts, in particular, the consumer has a vital interest in retaining their telephone number, as informing all contacts that there has been a change to that number can be both costly and time-intensive. To this end, mobile number portability has been introduced across all markets; in the EU, this right is now enshrined in Directive 2018/1972/EU, Art. 106). Extension of the contract benefits the provider by guaranteeing a customer, which in turn also guarantees a certain income. This allows the provider to amortise the initial investment in acquiring and signing up the new customer (Bar-Gill 2012). If renewal occurs completely automatically, there are no further transaction costs involved at the extension stage. The benefits come at a price to both parties though: The customer is bound for a long term and cannot take advantage of later cheaper offers; additionally, they might not be able to update handsets as frequently as they might wish. Changes in personal circumstances cannot be accommodated by changed contractual arrangements, unless the provider agrees, which they will typically only do for more expensive price plans. The provider, too, might face changed circumstances without being able to reflect them by adapting contract terms. They might be bound to honour contract terms for a longer term and at a lower rate than is commercially viable.

\section{The Law}

The picture as to the regulation of automatic contract renewal differs considerably across the jurisdictions under review here. Within the EU, a further harmonization will be achieved once the Electronic Communications Code (Directive 2018/1972/EU) has been implemented in the Member States as Art. 106(3) requires that after 'automatic prolongation [ ... ] end-users are entitled to terminate the contract at any time with a maximum one-month notice period'. This will require future changes to the laws discussed below; only English law seems compliant with this provision at the time of writing.

In Germany, contract terms stipulating automatic renewal by another fixed term are permitted, even in pre-formulated standard contracts, as long as the maximum renewal period of one year as laid down in BGB Section 309(9)(b) is not exceeded. ${ }^{3}$ This occurs without the consumer's explicit consent at the time of the extension. Renewal operates on the terms of the

\footnotetext{
3 This provision covers long-term contracts relating to the 'regular delivery of goods or the regular performance of services'. It is also applicable to cases of bundled performances, such as the provision of handset with subsequent regular provision of services (OLG Hamm 2016). Even if Section 309 No. 9 should be inapplicable, the same result would be achieved by applying the general clause in BGB Section 307.
} 
initial contract and even though no new handset is provided, the price remains the same; this has been held to be compatible with unfair terms legislation (AG Munich 2016, p. 62). The burden is on the consumer to give notice to terminate the agreement before expiry of the notice period. This approach is not, however, representative of the civil law tradition more generally. The two systems most closely related to German law, Austria and Switzerland do not allow automatic renewal unless the consumer has received a reminder about the extension not too long before the end of the initial period (Maissen 2012). Similarly, under French law, the consumer is only bound by an extension for a fixed period if the professional has sent a reminder of the extension within a one- to three-month period prior to the extension. If no such reminder was sent, the consumer can cancel the agreement at any time under Consumer Code, Art. L136-1 (OECD 2011, pp. 94, 99).

A sector-specific modification has recently brought German law somewhat more in line with the dominant civil law position. According to the Telecommunications Transparency Order 2015 Section 5, the provider must state on every monthly statement the end date of the agreement and the last date on which notice of termination can be given in order to avoid automatic renewal. This falls short of an explicit reminder though, as a notice on a statement is more likely to be overlooked than a separate notification. Nonetheless, for the first time, there is a sector-specific provision that takes some of the burden of having to remember renewal dates away from the consumer. This falls short of the prohibition of automatic renewal beyond one month that the EU Telecoms Code requires as of 21 December 2020 (Directive 2018/1972, Art. 124(1)).

In the UK, legislative changes based on EU law have taken a similar stance on automatic renewal, presuming the unfairness of such clauses unless the consumer has a right to indicate that he does not wish such renewal and the deadline to give notice is not unreasonably early (Consumer Rights Act 2015, sch. 2(9)). In principle, this could lead to contracting mechanisms as found in Germany or France. The telecoms regulator, OFCOM, has laid down stricter rules for telecoms contracts though and requires the consumer's explicit consent to an extension by another fixed period. If such consent is missing, the contract is converted into a contract of indefinite duration which can be terminated by giving one month's notice (Ofcom 2015a, s. 9.6). In Canada, the Wireless Code similarly provides for extension on a monthly basis only (Telecom Regulatory Policy 2013, Section G.6); where the customer is incentivized by receiving a new handset into accepting a new fixed term, their explicit consent must be obtained (ibid, para 277). This appears the same in practice as the future EU solution in the Electronic Communications Code (Directive 2018/1972); although Art. 105 does not mention explicit consent, such consent would constitute a new contract which would not be an automatically prolonged contract that is subject to cancellation by one-month notice. The consumer has the right to further opt out of the automatic extension on a monthly basis (ibid, para 275). Before the introduction of the Wireless Code, there was no legal basis in most of Canada's provinces regulating the automatic or unwanted extension of consumer contracts. The courts have subjected relevant clauses to a general test of good faith and honesty, with the associated problems of uncertainty and interpretive difficulties arising from such vague tests. Only in some provinces do statutory consumer protection measures apply.

In the USA, many states allow automatic renewal only after a reminder by the service provider. The Illinois Automatic Contract Renewal Act Section 10(b) stipulates that any extension by more than one month of a contract with an initial duration of 12 months or more is subject to the provider reminding the customer of the renewal between 60 and 30 days prior to renewal. Such notice has to include a reminder of the possibility of cancellation and explain 
that otherwise the contract will renew, and give advice on how to cancel the contract (815 Ill. Comp. Stat. 601/10 (2010)). In Florida, too, any extension of a contract of an original length of 12 months or more depends on the provider reminding the consumer of the impeding renewal between 60 and 30 days before the cancellation deadline (Fla. Stat. Section 501.165(2)(b)). The position is similar in New York (NY General Obligations Law, Section 5-903) and North Carolina (NC Gen. Stat. 2011, Section 75-41(a)(3)), where the deadlines for the reminder are slightly different and calculated from the cancellation deadline (NY) or the date of automatic renewal (NC), and in California (Cal. Bus. \& Prof. Code Section 17600-6 (2009)). These U.S. solutions are not dissimilar to the position taken in France (Code de la Consommation, Art. L136-1; see OECD 2011, p. 94).

\section{Business Influences}

Renewal on the same terms as during the initial commitment period has obvious commercial benefits for the mobile phone provider. During the initial period, the monthly price frequently contains an element for a subsidised handset. The initial contract is designed to amortise the cost of the handset during the initial period. Renewal without exchange of handset thus leads to a windfall for the provider who continues to receive payments for a handset that is already paid off.

As the renewal occurs on the same terms, there is, at least hypothetically, also a risk of the provider being tied to a contract on terms that have become commercially unattractive. Rather than being able to adjust the contract to reflect the increased cost, the provider would have to continue on now unattractive terms. On such an assumption, it might be explained why Germany has a higher price level than the other countries under consideration here: Given German law's hostility towards allowing unilateral price increases, providers have to anticipate future cost increases and charge a comparably high price from the beginning. As stated above, this hurdle is mainly hypothetical, as it can be overcome by the provider giving notice of a price increase effective from the date of the renewal. It is then the consumer's decision whether to allow the contract to renew on the changed terms, or whether to discontinue it. One reason why providers might be reluctant to notify customers of price increases is that this operates like a reminder of the impeding renewal, alerting the mobile phone user to the fact that they are in a position to terminate the agreement and look for alternatives elsewhere.

\section{Comparison with Early Termination}

Similar questions arise regarding the possibility of exiting the contract before the expiry of the initial term. In German law, early termination is not possible unless the contract is modified by the provider. The consumer is bound for the entire period they have agreed to, unless the service recipient moves house and the telephony services are not available at the new address (TKG Section 46(8)). Even if the consumer avails themselves of the possibility to port the mobile phone number to another provider, the existing contract will continue, and another phone number will be allocated: Section 46(4) TKG provides that 'the existing contract between the user and the previous provider ... is unaffected [by the mobile phone number porting]'. The consumer, in effect, is thus obliged to make all payments under the agreement. The contract continues to operate between the parties - pacta sunt servanda. In addition, a 
disincentive to porting one's mobile phone number to another provider is that, unlike most other countries, where the porting service is free, fees of up to $29.95 €$ may be charged by the previous provider for releasing the mobile phone number; even higher fees were charged, up to $116 €$, before the Telecoms Regulation Authority introduced this cap in 2004 (see Bundesnetzagentur 2004). This mirrors the general payment structure prevalent in Germany that services are paid for individually on the basis of actual use rather than via hidden default costs. ${ }^{4}$ In the UK, typically no fees for number porting are charged, although the industry regulation would allow charges that are 'cost oriented and based on the incremental costs of providing portability' as long this is reasonable (Ofcom 2015a, para. 18.5). As a consequence of the Electronic Communications Code (Directive 2018/1972) Art. 106(4), in the future, no direct charges can be applied to end-users in EU Member States.

In contrast to the continued existence of the contract in German law, in the common law jurisdictions, consumers can, in principle, exit their agreements before the expiry of the term. This constitutes repudiation of the contract and gives rise to a claim for damages by the service provider against the customer. In practice, the amount of damages is usually laid down in the contractual agreement as an early termination fee (Ofcom 2015b, para 69). In the UK, this fee is calculated by reference to the monthly subscription price multiplied by the number of months remaining in the agreement (Ofcom 2015b, para 58). OFCOM, the UK telecoms regulator, has identified the early termination fee as a default charge, payable as a result of the consumer's breach of contract, not a price payable in exchange for the service provided. The charge is therefore subject to the assessment for fairness under the term control provisions of the Consumer Rights Act 2015 (Ofcom 2015b, para 73). The charge thus must be a fair reflection of the provider's anticipated factual loss. In practice, providers charge an amount equivalent to the remaining monthly payments with a discretionary reduction if that amount is paid in full. It is doubtful that this is fully compliant with the fairness requirement, as no discounts are specified for the costs that have been avoided or any other savings the provider has made as a result of the customer's early termination (Ofcom 2015b, para 80).

In Canada, the fee charged for early termination is limited to the value of a subsidised handset and must be reduced in accordance with the remaining duration of the initial term (Telecom Regulatory Policy 2013, G-2) or, where no subsidized handset was part of the contract, $10 \%$ of the minimum monthly charge for the remaining months of the contract up to a maximum of CAN $\$ 50$ (Telecom Regulatory Policy 2013, G-3). The Canadian position is thus much more beneficial for consumers, in particular in contracts without a subsidized handset. Here, the contrast with the UK is the greatest, where the monthly subscription price remains payable even in contracts where no handset was provided as part of the agreement, or where the service agreement and handset credit agreement are legally separate (Fitchard 2015).

In the USA, early termination charges used to be set as fixed amounts that remained unchanged during the course of the agreement. This practice has changed after several lawsuits

\footnotetext{
${ }^{4}$ See Kenny (2011), p. 45 for a comparison of bank charges. In Germany, typically, current bank accounts cost a small monthly subscription fee, and many banking transactions attract small service fees. Overdrafts, on the other hand, are charged a relatively low rate of interest and often do not incur additional fees; where lump sum fees are charged, BGH (2016) has declared that these breach unfair term. In the UK, most current accounts are free of charge, as are cash withdrawals and other banking transactions, which are paid for by hefty overdraft fees and high overdraft interest. The national courts have taken opposing views as to the nature of certain bank fees and the resulting possibility to assess their fairness under unfair terms legislation. The UK Supreme Court has held overdraft fees to constitute payment for the banking services and, as such, not subject to the assessment for fairness (Office of Fair Trading v Abbey National 2009). In Germany, ancillary banking fees have repeatedly held to be subject to the assessment for fairness (BGH 1993; BGH 2001; BGH 2005).
} 
were brought against mobile phone providers (Ayyad v Sprint Spectrum L.P 2012; Larson v Sprint Nextel Corp 2009) and fees are now typically dependent on the type of handset provided under the agreement (standard or smartphones) and the length of the remaining contract period. The difference between this and the English or Canadian position is that the early termination fee is calculated without reference to the monthly payments due under the mobile phone agreement. There are thus very evident differences among common law jurisdictions when it comes to the calculation of the early termination fee. The English position is based on general contract law principles and focuses on what the provider might have recovered in an action for the price or damages. The Canadian position puts competition at the centre of the argument. Here, it is considered important that an early termination fee can be charged even for contracts where no subsidised handset was provided, as 'banning an early cancelation fee in the above-mentioned circumstances could reduce consumer choice by reducing the incentive for [service providers] to offer service plans featuring discounts or lower rates in return for customers signing fixed-term contracts' (Telecom Regulatory Policy 2013, para. 227). The overall consideration is that 'the amount of the early cancelation fee should be limited to ensure that it does not constitute a switching barrier' (ibid.).

The stark contrast with the German position is that the contract is brought to an end. In Germany, the contract survives the attempt to prematurely terminate it and the consumer is required to make all contractual payments until the end of the minimum term. As with automatic renewal, German law upholds the tie between the parties created by their agreement. The common law finds it easier to allow parties to exit an agreement and uses early termination fees as a way of ensuring the provider's commercial expectation is not undermined. The differences in the amount that can be charged in the jurisdictions under discussion appears to be a consequence of the varying policies pursued by local lawmakers. As the purpose of the Canadian Wireless Code is to boost competition in a market that was perceived as lacking competition, exiting an agreement was made as cheap as possible, while still allowing some compensation for the provider. In the UK, the policy focuses more on the contractual bargain struck by the parties and therefore solely subjects the term providing for an early termination charge to the assessment of fairness under unfair terms legislation. The same appears to be true in the USA, where, in the absence of specific legislation on unfair terms, the general doctrine of contractual penalties is used to reduce previously fixed penalty payments to a prorated system. Penalty clauses are unenforceable in the Restatement (2d) of Contracts Section 356 and Uniform Commercial Code (UCC) Section 2-718. Both instruments distinguish liquidated damages clauses as clauses providing for 'an amount that is reasonable in the light of the anticipated or actual loss caused by the breach and the difficulties of proof of loss' (Restatement (2d) of Contracts Section 356(1)); the wording of the UCC is similar but goes on to include 'the inconvenience or non-feasibility of otherwise obtaining an adequate remedy'.

\section{Modification}

The last factor influencing the overall balance of rights and duties between the parties is the possibility of modifying the terms of the agreement during the initial (or a subsequent) commitment period. At the outset, we need to remember that neither party has the power, once a contract has been validly created, to unilaterally change the content of the agreement. This might cause hardship to the provider where there is a substantial increase in cost associated with providing the telephone services contracted for. Conversely, the consumer 
benefits from knowing that during the initial commitment period at least there will be no price increases. In the absence of an agreement to the contrary, though, the provider cannot change the price, or any other term, during the duration of the agreement. The key question is thus to what extent do the different jurisdictions considered here permit providers to include contractual terms allowing for the possibility of a modification of the contract terms, in particular, a price increase? Within the EU, there are two levels of control of contract terms purporting to allowing the provider subsequently to increase the price of the mobile phone services offered. In general contract law, the unfair contract terms directive presumes the unfairness of a term in standard form contracts allowing a price increase "without ... giving the consumer the corresponding right to cancel the contract if the final price is too high in relation to the price agreed when the contract was concluded' (Directive 93/13/EEC, Annex 1(1)), which has been interpreted by the European Court of Justice (CJEU) in RWE Vertrieb $A G v$ Verbraucherzentrale Nordrhein-Westfalen eV (2013), as allowing price variation clauses if 'the contract sets out in a transparent fashion the reason for and method of the variation of those charges, so that the consumer can foresee, on the basis of clear, intelligible criteria, the alterations that may be made by those charges'. At industry level, Council Directive 2018/1972, Art. 105(4) provides that 'end-users have the right to terminate their contract without incurring any further cost upon notice of changes in the contractual conditions proposed by the provider'. The predecessor to this provision (Directive 2002/22, Art. 20(2)) was interpreted by the CJEU as not applying to a term in a contract that links price increases to 'changes in an objective consumer price index compiled by a public institution' (Verein für Konsumenteninformation v A1 Telekom Austria AG 2015, para. 26). Both provisions have found a different reception in the Member States.

In the UK, under general contract law, price increases in mobile phone contracts are mostly regarded as acceptable. Under the Consumer Rights Act 2015, terms may be regarded as unfair if they allow 'the supplier to alter the terms of the agreement unilaterally without a valid reason which is specified in the contract', in particular if the effect is 'to increase the price ... without giving the consumer the right to cancel the contract if the final price is too high in relation to the price agreed when the contract was concluded'. 5 The body in charge of giving effect to consumer legislation, the Competition and Markets Authority (CMA), issued guidance that ' $[\mathrm{t}] \mathrm{erms}$ which permit increases linked to a relevant published price index such as the RPI are likely to be acceptable' (Ofcom 2015b, para. 12.4). The Court of Appeal held that price increases generally would be permissible if they were 'part of a carefully balanced review procedure' which had been fairly applied in the instant case (Du Plessis v Fontygary Leisure Parks Ltd 2012, paras. 49, 52). In general, there is thus some room for contract terms allowing price changes, as long as the process for determining the change is spelt out with sufficient clarity in the contract term.

The corresponding provision relating to price increases in the sector-specific regulations is contained in General Condition 9.6, which applies only to 'modifications likely to be of material detriment' to the consumer. The position originally taken by the Telecoms Regulator was that price increases in line with inflation were not of material detriment to the consumer. In January 2013, the Telecoms Regulator OFCOM launched a consultation and concluded that price changes were likely to be of material detriment to the consumer as ' $[\mathrm{t}]$ he core subscription price is one of the most important factors in the subscriber's choice of contract. It is likely to be the most important aspect of one of the key terms of the contract' (Ofcom 2013b, para.

$\overline{{ }_{5}^{5} \text { Previously UTCCR sch. 2, no. } 1}$ paras. j, 1. 
A1.10). For the purposes of the sector-specific regulation, OFCOM does now consider terms allowing discretionary price increases as being to the material detriment of the consumer; by contrast, contractually agreed price increases, whereby it is clear that at a certain point in time the price will increase by a stated amount, or by a stated percentage in line with an inflationary measure (such as the retail price index, RPI) are not considered to be of material detriment to the consumer (Ofcom 2013b, para. A1.14), which mirrors the position taken by the European Court of Justice in Verein für Konsumenteninformation v Al Telekom Austria AG (2015). This is dependent on 'the relevant price terms being sufficiently prominent and transparent that the subscriber can properly be said to have agreed on an informed basis, at the point of sale, to the relevant tiered price(s). Where that is so, the application of the agreed price(s) at the relevant time(s) would not be a modification of the amount he or she has agreed and is bound to pay' (Ofcom 2013b, para. A1.15). This approach is in line with the approach taken under the general law and emphasizes the knowledge of the consumer of the possibility of a price increase, and the adherence of the supplier to the stated procedure to determine the increased price. In sum, it is relatively straightforward to include a term regarding price increases in mobile phone contracts in the UK. The fact that mobile phone contract prices are lower in the UK than in any of the other markets under discussion might suggest that the relative ease with which providers can increase the contract price leads to restraint when the initial contract price is set.

In Canada, the Wireless Code now prohibits any changes to key contract terms (content of service, monthly charge, contract term) without the consumer's informed and express consent, and the consumer has the right to refuse the proposed change (Telecom Regulatory Policy 2013, paras 92-93). The prohibition of changes to the contract terms, unless they solely benefit the consumer, is based on the finding that 'requiring the customer to either accept the change or cancel the contract, which may involve the customer incurring an early cancelation fee, is insufficient to address consumer concerns' (Telecom Regulatory Policy 2013, para 88). This line of reasoning is not entirely convincing as it would be perfectly possible to say that cancellation on grounds of a change to core contract terms does not trigger the early termination fee. This option, it appears, was not considered when the regulatory policy was developed. Consequently, the Canadian position is, again, very generous towards the consumer and forces the provider to honour the terms of an agreement that might not be as profitable as expected. In contrast to the UK position, though, providers might factor in potential future price increases into the original contract price explaining, at least in part, the overall higher prices in Canada.

In the USA, where there is no sector-specific regulation of the issue, an adverse, material change to the contract terms justifies termination of the agreement under all operators' terms of contracting. There is some debate about unilateral modification clauses in contracts in general (Bar-Gill and Davis 2010; Horowitz 2006; Watkins 2009) and for credit agreements in particular. For the latter type of agreement, federal legislation has in narrowly defined circumstances outlawed (Truth in Lending Act Section 226.5b(f)(3)) the use of unilateral modification clauses and otherwise provided specific notification requirements (Credit Card Accountability, Responsibility and Disclosure Act 2009, s. 101(a) (1)). State law has proved rather accommodating to banks' wishes to unilaterally alter terms (Alces 2009). Outside the realm of credit agreements, there appear to be no statutes of general application dealing with unilateral modification of contracts; Alces (2009, p. 1130) mentions as the only sector-specific example landlord-tenant legislation. Courts have occasionally employed general contract doctrines instead. In Powertel Inc v Bexley (1999), the doctrine of unconscionability was used 
to strike out a compulsory arbitration clause that the service provider had inserted into customers' contracts, relying on a change-of-terms clause in the original agreement. The test for unconscionability was included in the UCC (Uniform Commercial Code Section 302) and has been refined in case law (Knapp 2013); it has subsequently been absorbed in Restatement (2d) Contracts Section 208. Unconscionability has been widely used by the courts to deal with mandatory arbitration clauses in contracts (Knapp 2013); the mere combination of such a clause and a change in terms provision in the contract does not per se render mandatory arbitration clauses unconscionable as the U.S. Court of Appeals for the 5th Circuit held in a class action against mobile phone providers (Iberia Credit Bureau, Inc v Cingular Wireless $L L C$ 2004). In many respects, US-style unconscionability resembles the general European test for the assessment of fairness of terms as applied in the UK, France and Germany. In the leading case Williams $v$ Walker-Thomas Furniture Co (1965), unconscionability was taken to be present where there is 'absence of meaningful choice on the part of one of the parties together with contract terms which are unreasonably favourable to the other party'. This test contains procedural and substantive elements (Leff 1967, p. 487), both of which must be present (Garrett v Janiewski 1985) on a sliding scale (A\&M Produce Co. v FMC Corp. 1982). In standard form contracts, the adhesive nature of the contract in itself satisfies the procedural element (Flores v. Transamerica HomeFirst, Inc., 2001). Herein lies the similarity to the European approach, where Article 3 of the Unfair Terms Directive (93/13/EEC) provides: 'A contractual term which has not been individually negotiated shall be regarded as unfair if, contrary to the requirement of good faith, it causes a significant imbalance in the parties' rights and obligations arising under the contract, to the detriment of the consumer' ${ }^{6}$ The procedural element is the limitation to terms that have not been individually negotiated, and the additional requirements, such as transparency as per Unfair Contrac Terms Directive, Art 5. The substantive requirement is the significant imbalance in rights and obligations to the detriment of the consumer. A difference in the European system is that this general clause has been further concretised by a list of clauses that the legislator has identified as being potentially unfair. One of those presumed unfair terms is a clause allowing discretionary price increases (Unfair Contract Terms Directive, Annex 1(1)). In the UK, as was seen above, it was held that price increases were permissible if the procedure for determining the new price had been clear and had been applied fairly in the instant case.

The position is rather different in German law. First, there is no sector-specific regulation regarding mobile phone contracts; the Telecommunications Act does not contain any provisions on pricing. The general provisions regarding price escalation clauses in contracts are based on the same European rules as in the UK but have been differently interpreted. Section 308 Nr. 4 of the German Civil Code prohibits unilateral modification clauses in standard terms, unless agreeing to such a term can be reasonably expected from the consumer, taking into account the interests of the other party to the contract. This prohibition covers clauses modifying the supplier's obligations only, not the price payable for it. In Germany, clauses which are not individually negotiated which allow for a price increase are held to be void where they are "contrary to the requirement of good faith [...] unreasonably disadvantageous' to the consumer (BGB Section 307). With respect to price increase clauses, German courts apply a very high threshold (Atamer 2017, p. 626), criteria that 'no market player seems

\footnotetext{
${ }^{6}$ Council Directive 93/13 implemented (and extended to individually negotiated terms) in the UK in Consumer Rights Act 2015, ss 63-76 (the previous implementation in the UTCCR reg 5 followed the European text more closely), implemented in Germany in BGB Sections 305, 307.
} 
to be able to fulfil anymore' (Rott 2013). The consumer has a right to terminate the agreement if the price increase is fractionally above the increase of the general cost of living (BGH 1984). In order to comply with the transparency requirement, such clauses are further only valid if the professional's power to increase the price is made dependent on an increase in cost, and the specific cost elements as well as their respective weighing are laid open in the calculation of the total price' (ibid). The mobile phone supplier thus ought to disclose vital commercial information - its pricing calculations - in order to achieve a price escalation clause that can lead to a price increase without a corresponding right on the consumer's side to terminate the agreement. In light of the strict requirements, academic commentators go a step further and say that the consumer must have a right to cancellation for every price increase (Zschieschack 2018). The recently introduced English practice of price rises agreed in advance in line with a general price index would fall foul of the general prohibition of price index clauses in contracts in Germany (Preisklauselgesetz), as these are seen as contributing to inflation, a wider societal consideration rather than a mechanism of consumer protection, which nevertheless has an impact on consumer contracts (Dodsworth 2015). Under this Act, automatic price escalation clauses are allowed in very narrow circumstances only, and if so, authorisation requirements are imposed for several areas of commerce. Prior to the introduction of the Euro, the prohibition of automatic price escalation clauses was even stricter under the Price Clause Order (Preisklauselverordnung 1998).

The position regarding unilateral modification, in particular price escalation, is thus a diverse one. Canada and Germany de facto do not allow such clauses, but for very different reasons and by providing for different regimes. In Canada, the consumer is protected from unforeseen price rises and at the same time from having to make new arrangements as the contract has to be continued on the previous terms if the consumer does not agree to the increase. In Germany, the consumer is granted an extraordinary right to terminate the agreement in case of a price increase, unless such increase meets the very strict requirements of a permissible increase. This may be an explanation for the higher prices found in Germany in relation to mobile phone contracts.

\section{Trade-Offs Between the Factors}

This paper has discussed the three features which define a long-term contractual relation from a regulatory point of view: initial commitment period, renewal and modification. It was shown that each of the features is shaped by a plethora of factors from technological advancements to cultural and political beliefs. It further transpires that although each of the features, if compared separately, provide for differing levels of consumer protection, once taken together, the level of protection (whether through regulation or market pressure) in each of the jurisdictions is similar, unless there has been drastic regulatory interference (which then has a significant impact on the price). For example, where a jurisdiction gives more power to the service provider with regard to the initial commitment period, it tends to provide the consumer with more protection in relation to the renewal and modification. Certain increased protective features are traded off against lower levels of protection regarding a different aspect of the contract. These findings can be transferred to other types of long-term contracts, because the commercial interests are similar to those in the mobile phone industry. Differences arise only where the regulation of a particular market pursues very strong policy aims specific to that market, such as the introduction of greater competition in the Canadian mobile phone market. 
The balancing effect can be illustrated by looking at the initial commitment period in Germany which has been 24 months since before the age of mobile phones. German law allows the service provider to renew the contract after the 24 months (so long as the consumer agreed to this in the initial contract) for an additional 12 months without any duty to notify the consumer. However, the service provider will not (apart from the very restrictive option mentioned above) be able to modify the terms during the contract. In this example, the renewal in favour of the service provider is traded off against the rules on modification weighed in favour of the consumer.

A similar trade-off is also apparent in the English approach. The initial commitment period is limited to 24 months, though this is a European influence, and the service provider can reasonably easily modify the terms of the contract. However, there is no possibility for the provider to renew the contract without express consent from the customer beyond a one-month rolling basis. Compared to Germany, in the UK, mobile phone contracts renew less easily but can more easily be modified, striking a balance between the parties' interests that is not far removed from the balance struck by German law.

The position in the US reveals a similar approach to that in Germany although it is noticeable that this is not due to regulation but to how the industry has reacted over time. Providers can, without the consumer's explicit consent, renew the contract. There is no legal limit on the initial length of the contract, though unconscionability may allow a review of an excessive initial commitment period, which would explain why there are no consumer contracts offered for a period of more than 24 months. Although technically there is the opportunity to modify the contract, it seems that the uncertainty, especially in light of the doctrine of unconscionability discussed above, means that in practice providers will not make use of it. This means that despite specific regulation the balance of interests, while different in detail, consumer protection is effectively in line with that found in Germany and England.

By contrast, Canada is an example of regulatory intervention which has given consumers more comprehensive rights. This is a consequence of the imbalance in favour of the service provider that had existed before regulatory intervention, and that the real motivation behind the intervention was to create greater competition in the telecoms market. A consequence of the focus on consumer interests is that package prices in Canada remained high until 2016 (NGL Nordicity Group Ltd., 2017 p. 80, fig C.2). The USA, on the other hand, is an example of how a similar level of consumer protection to that found in Germany and England is reached without much regulatory intervention.

The knowledge that there are three factors that shape the nature of a long-term, consumerprovider relationship will help in identifying how to regulate, if at all, each element. However, it is also important to consider why countries may have decided to directly or indirectly regulate the long-term relationship in the way that they do. The next section will determine each jurisdiction's choice of weighting in relation to these factors.

\section{Policies}

Underlying every legal rule is a policy aim pursued by the lawmaker. Here, we will discuss the different policies adopted in the jurisdiction under discussion. At first sight, it could be argued that the policies of the different jurisdictions are merely based on their legal heritage, i.e., whether they belong to the civil or common law family. Three of the countries, the UK, Canada and the USA, share a common heritage in form of the common law, which might 
suggest that they are influenced by shared legal principles, which in turn may better explain the difference in approach to that taken in Germany. However, any differentiation into legal families (Zweigert and Kötz 1998) is overly simplistic (Glenn 2012), and wrongly emphasizes perceived similarities rather than the very real differences between countries belonging to the same legal family.

This is clear when we consider that there is no generally accepted civil law position on automatic renewal and Germany appears quite alone in rather generously (for the provider) allowing automatic extension by up to one year without the consumer's explicit consent. The recently introduced more consumer-friendly measures (Transparency Order) only oblige the provider to mention on each statement and the beginning and end dates of the agreement, as well as the last possible day to cancel it. This shows that within the civil law family alone, two different approaches can be traced (Dodsworth et al. 2014; OECD 2011, p. 96). The first is the business-friendly approach taken by German law; the second, and dominant approach, is the imposition on the business of a duty to remind the customer of the impending renewal as found in, e.g., French and Austrian (Maissen 2012) law. While there are thus clear differences within the civil law countries, it is noticeable that none of them go so far as to require the customer's explicit consent, at the time of renewal, for such a renewal to take effect, as long as the customer agreed to potential renewal when entering into the contract. A similar position is that taken in many U.S. states. This means that although the division between civil law and common law families may explain the differences in approach to a certain extent, the divergence of approaches within those families tend to suggest that there are other factors which have influenced the legislative decisions in this area.

The common law position is similarly split, as in the UK and Canada the yardstick that is now employed for renewal is the consumer's explicit consent, whereas in the USA, reminders by the provider are prevalent. It is noticeable though that in the UK and Canada, this shift in policy was introduced on an industry-specific regulatory basis, rather than as a matter of general law (Ofcom 2015a; Telecom Regulatory Policy 2013). It is further of interest to note that the motivation behind the policy appears to be rather different in the two countries.

The CRTC analyses automatic renewal in the following terms: 'The lack of transparency regarding contract extensions is a key concern for consumers. This lack of transparency can be detrimental to a dynamic market since it acts as a barrier to switching [wireless service providers] by locking consumers into another contract term when they may not wish this to happen' (Telecom Regulatory Policy 2013, para. 273).

The UK Telecoms regulator, OFCOM, on the other hand, places greater emphasis on the individual consumer's position and states that automatic renewal has 'the effect of reducing switching by locking consumers into long contract terms with financial penalties ... for exit [which] is likely to be harmful for [consumers] who are discouraged from switching' (Ofcom 2011, para 17). In addition to the damage to competition, the regulator emphasizes that tie-in clauses might prevent consumers 'from switching supplier to take advantage of new offers' and describes this 'source of harm' as only affecting 'the individual subject to the ARC term' (Ofcom 2011, para. 3.22). Only much later in the analysis is it recognised that '[s]witching costs can also harm competition' (Ofcom 2011, para. 3.40).

While both regulators put 'consumer switching' at the centre of the argument, the English regulator emphasises the individual detriment to the consumer, the Canadian regulator the detriment to competition in the wireless telephone market. The underlying purpose of the Canadian Wireless Code is 'to contribute to a more dynamic wireless marketplace' (Telecom Regulatory Policy 2013, para 216) and to increase competition (OECD 2016) where 
previously a general lack of competitiveness had been lamented (Masse and Beaudry 2014); tying consumers into long-term contracts that are automatically renewed would be an obstacle to achieving this end. In the UK, a concern for the individual customer - and therefore the customer's autonomy - goes a long way in explaining the need for explicit consent by the customer to any renewal. Similarly, a concern for competition in the market explains the Canadian approach to restricting the provider's right to renew the contract automatically. The difference in the motivation behind both approaches is one of degree rather than substance, but it is nevertheless an important shift in emphasis (as to the motivation of the European legislator), see Universal Service Directive (2009/136/EC).

A further difference in policy is the approach to modification. It was outlined above that German law does not allow price rises in line with the retail price index. The reasoning seems to be that this might be a driving force for inflation. The need to avoid such inflation stems from the hyperinflation of the 1920s which caused significant disruption in Germany (Dodsworth 2015). Despite the general principle of nominalism in the UK (ibid. p. 279), a less restrictive approach prevails there, and OFCOM has specifically highlighted that there is no disadvantage to the consumer at all in allowing for a price rise in line with inflation (Ofcom 2013b, para A1.14).

The first decision for any jurisdiction considering its attitude towards long-term contracts would be whether this type of contract should be regulated individually or whether a more overarching framework might suffice. The answer will lie in the policies of that jurisdiction which may need an overarching framework beyond that of consumer protection in the specific market segment, such as in Germany (the protection against inflation). The need for direct, strategic intervention could be based on a failure of the market (such as in Canada) or the need to protect the autonomy of the individual (as in the UK). In a competitive market, an overarching approach will most likely be more future-proof, with new technologies on the horizon. However, such an approach my stifle the introduction of new types of contract. As the example of Canada has shown, simply adopting an overall consumer protectionist approach on all levels can have adverse effects on the price level or competition.

\section{Conclusion}

This article has established that there are three factors which shape long-term mobile phone contracts. First, that long-term mobile phone contracts, in addition to price, are designed around three factors: the initial commitment period, the possibility of the contract automatically renewing and the service provider's ability to unilaterally modify the contract. Second is that the balance of the interests of provider and consumer is rather similar cross jurisdictions due to trade-offs between these features. Only where an external overbearing regulatory aim interferes, such as in Canada, can the balance be tipped clearly in favour of one party. But the protection afforded to consumers in that case is not an end in itself; it is a reflex of the underlying desire to open the market for more competitors by creating a higher level of competition.

Third, the article has identified the policies followed by each of the jurisdictions. In Canada, in reaction to a market dominated by only a few large providers, policy was focused primarily on creating a competitive environment. In the absence of regulation, a rather business-friendly system had established itself. This has not been the case in the USA, where there has been greater competition among mobile phone providers. The geographical extent and sparse 
population of Canada have made regulatory intervention necessary to boost competition. The English approach, in line with the general approach to contract law, favours individual, in particular procedural, fairness. Germany's approach, in line with the rationale underpinning unfair contract terms legislation there, is centred on protection of society as a whole. The absence of specific regulation in the USA is evidence of the pursuit of a free market policy. Regardless of policy position, with the exception of Canada which can be explained on the basis of the far reaching regulatory intervention necessitated by external factors, the level of protection for consumers regarding contract design is similar.

The above findings indicate that, as long as there is competition, regulatory intervention has a limited impact. If anything, its consequences tend to be negative for the customer, resulting, e.g., in higher prices or less competition. The example of a maximum permissible duration for contracts has shown that this legal interference leads to most contracts congregating at or near the top end. The focus, therefore, on consumer and customer protection is a less-effective approach than focusing the creation of a competitive mobile phone market. It can thus be concluded that regulation provided by the general doctrines of contract law is sufficient to provide the required level of protection so long as there is a sufficiently competitive market. The adverse effects of regulation in a welfare state are discussed by Posner (1995).

These findings can be applied to certain other types of long-term contracts more generally; some more traditional forms of long-term relationships follow different rules, e.g., tenancy agreements, due to the property law implications. In modern commerce, there is a trend towards long-term contractual relations rather than outright one-off transfers; this so called 'subscription economy' (McKinsey 2018) has gathered pace with the advent of e-commerce, and in particular m-commerce, which is facilitated by mobile telephony. The clear implication is that regulators of this new type of subscription model as well as of some more established markets which commonly deal with long term contracts would be advised to focus their efforts on creating competitive markets for example by nudging consumers towards overcoming their switching inertia rather than regulating the substantive contract. A successful example is the current account switching guarantee in the UK, created as a result of the Payment Account Regulations 2015; current account switching rates have increased as a result of the assurances provided for bank customers (Atamer 2017, p. 651); no attempt at regulating the contractual relationship between banks and their customers in this respect has been made though. An example that is likely to be less successful is the recently introduced energy price cap in the UK, which creates a significant interference with the principle of freedom of contract and is unlikely to stimulate switching (Bisping and Dodsworth 2019). However, where it is not possible to create a competitive market, the regulator would be advised to ensure regulation of all three factors and to be aware of the possible adverse effects of setting absolute upper limits, but this may have the consequence of overall higher prices. This paper provides the following insights that might serve as guidance to legislators and regulators. In long-term contractual relationships, the law should aim to strike a fair balance between the interests of the parties. It should provide sufficient foreseeability and predictability to both parties that they will be able to rely on the contract for an adequate amount of time; the customer should not have to fear to be left without supply, the provider should be able to rely that the cost of acquisition translates into an adequate profit over the currency of the agreement. In order to receive continued supply, there should be mechanisms for the contract to be extended on the expiry of its original term, such extension requiring the consent of both parties, express or implied. The law should further allow the required level of flexibility when it comes to adapting the terms of the contract; external changes to price-influencing factors should be 
accommodated to the extent that the mechanism for doing so is clear to the parties and transparent. Regulating the substance of the contract beyond these parameters does not bring any positive effects.

\section{Legislation}

1. USA

a. 47 US Code 2012

b. Automatic Contract Renewal Act 2000, 815 ILCS 601/1.

c. California Business and Professions Code 2009

d. Cell Phone User Bill of Rights, S. 1216, 108th Cong 2003

e. Credit Card Accountability, Responsibility and Disclosure Act, 2009, Pub. L. No. 111-24, 123 Stat. 1734, (amending 15 U.S.C. § 1637(i))

f. MA S1617. (2013). An Act establishing a cell phone users' bill of rights, the 188th General Court of the Commonwealth of Massachusetts, 2013-2014

g. Minnesota Statutes 2004 (expired on Aug. 1, 2007)

h. New York Consolidated Laws, General Obligations Law

i. Uniform Commercial Code, 1977

j. Truth in Lending Act, 12 C.F.R.

2. UK

a. Unfair Terms in Consumer Contracts Regulations 1999 (SI 1999/2083)

b. Consumer Rights Act 2015

c. Payment Accounts Regulations 2015 (SI 2015/2038)

3. France

a. Code de la Consommation [Consumer Code]

4. Germany

a. Bürgerliches Gesetzbuch [BGB] [Civil Code] 1900

b. Preisklauselgesetz [PrKG] [Price Clause Act] BGB1 2007 I 2246-7

c. Preisklauselverordnung [PrKV] [Price Clause Order] BGBl 1998 I 1429

d. Telekommunikationsgesetz [TKG] [Telecommunications Act]

e. Transparenzverordnung für den Telekommunikationsbereich [TK-TransparenzVO] [Transparency Order]. BGB1 2016 I 2937

5. European Union

a. Directive 93/13/EEC of 5 April 1993 on Unfair Terms in Consumer Contracts. Official Journal of the European Communities L95, 29

b. Directive 2002/22/EC on Universal Service and Users' Rights relating to Electronic Communications Networks and Services (Universal Service Directive). Official Journal of the European Communities L 108, 51

c. Directive 2009/136/EC amending Directive 2002/22/EC on universal service and users' rights relating to electronic communications networks and services, Directive 2002/58/EC concerning the processing of personal data and the protection of privacy in the electronic communications sector and Regulation 
(EC) No 2006/2004 on cooperation between national authorities responsible for the enforcement of consumer protection laws. Official Journal of the European Union L 337, 11

d. Directive 2009/140/EC amending Directives 2002/21/EC on a common regulatory framework for electronic communications networks and services, 2002/19/ $\mathrm{EC}$ on access to, and interconnection of, electronic communications networks and associated facilities, and 2002/20/EC on the authorisation of electronic communications networks and services. Official Journal of the European Union L 337, 37

e. Directive 2018/1972/EU establishing the European Electronic Communications Code (Recast). Official Journal of the European Union L 321/36

f. Regulation (EC) No 1211/2009 establishing the Body of European Regulators for Electronic Communications (BEREC) and the Office. Official Journal of the European Union, 1

g. The Treaty on the Functioning of the European Union (TFEU). Official Journal of the European Union. 2008/C 115/1

\section{Cases}

1. England and Wales

a. Du Plessis v Fontygary Leisure Parks Ltd [2012] EWCA Civ 409

b. Office of Fair Trading v Abbey National and Others [2009] EWCA Civ 116

2. Germany
a. AG Munich, 25/2/2016 - 213 C 23672/15. MultiMedia und Recht 2017, 62
b. BGH (1984), 01/02/1984 - VIII ZR 54/83, BGHZ 90, 69
c. BGH (1993), 30/11/1993 - XI ZR 80/93, BGHZ 124, 254
d. BGH (2001), 13/02/2001 - XI ZR 197/00, BGHZ 146, 377
e. BGH (2005), 07/03/2005 - XI ZR 154/04, BGHZ 162, 294
f. BGH (2016), 25/10/16, XI ZR 9/15 and XI ZR 387/15, BGHZ 212, 329
g. OLG Hamm (2010), 08/04/2010, I-17 U 203/09, MDR 2010, 1175

3. European Union
a. RWE Vertrieb AG v Verbraucherzentrale Nordrhein-Westfalen eV (Case C-92/11) ECLI:EU:C:2013:180
b. Verein für Konsumenteninformation v Al Telekom Austria AG (C-326/14) ECLI:EU:C:2015:782

4. USA
a. A\&M Produce Co. v FMC Corp. (1982) 186 Cal Rptr. 114
b. Ayyad v Sprint Spectrum L.P. (2012) 148 Cal. Rptr. 3rd 709
c. Flores v. Transamerica HomeFirst, Inc. (2001) 113 Cal. Rptr. 2d. 376, 283
d. Garrett v Janiewski 480 So. 2d 1324, 1327 (Dist. Ct. App. 1985)
e. Iberia Credit Bureau, Inc v Cingular Wireless LLC 379 F.3d 159 (5th Cir. 2004)
f. Larson v Sprint Nextel Corp (2009) WL 1228443 


\section{g. $\quad$ Powertel Inc v Bexley 743 So. 2d 570 (Dist. Ct. App. 1999) \\ h. Williams $v$ Walker-Thomas Furniture Co 350F.2d 445, 449 (D.C. Cir. 1965)}

Open Access This article is distributed under the terms of the Creative Commons Attribution 4.0 International License (http://creativecommons.org/licenses/by/4.0/), which permits unrestricted use, distribution, and reproduction in any medium, provided you give appropriate credit to the original author(s) and the source, provide a link to the Creative Commons license, and indicate if changes were made.

\section{References}

Alces, P. A. (2009). They can do what?! Limitations of the use of change-of-terms clauses. Georgia State University Law Review, 26, 1099-1145.

Ante, S. E. (2008). The call for a wireless bill of rights. Business Weekly, 80-81.

Atamer, Y. M. (2017). Why judicial control of price terms in consumer contracts might not always be the right answer - Insights from behavioural law and economics. Modern Law Review, 80, 624-660.

Bar-Gill, O. (2012). Seduction by contract: Law, economics, and psychology in consumer markets. Oxford: Oxford University Press.

Bar-Gill, O., \& Ben-Shahar, O. (2013). No contract? (Coase-Sandor Institute for Law \& Economics Working Paper, No. 636). Retrieved from: https://chicagounbound.uchicago.edu/cgi/viewcontent.cgi?referer= https://www.google.co.uk/\&httpsredir=1\&article=1334\&context=law_and_economics. Accessed 17 Dec 2018.

Bar-Gill, O., \& Davis, K. (2010). Empty promises. South California Law Review, 84, 1-46.

Bar-Gill, O., \& Stone, R. (2012). Pricing misperception: Explaining pricing structure in the cellular service market. Journal of Empirical Legal Studies, 9, 430-456.

Bell, J. (1989). The effect of changes of circumstances on long term contracts. In D. Harris \& D. Tallon (Eds.), Contract law today: Anglo-French comparisons (pp. 199-243). Oxford: Clarendon Press.

Bisping, C., \& Dodsworth, T. (2017). The heat is on - Could a cap on gas \& electricity harm customers in the long run? New Law Journal, 167, 10.

Bisping, C., \& Dodsworth. T. (2019). 'Energy Price cap - a disservice to consumers? EuCML (forthcoming).

BT. (2018). Market share held by mobile operators in the United Kingdom (UK) 2018, by subscriber. Statista. Retrieved from: https:/www.statista.com/statistics/375986/market-share-held-by-mobile-phone-operatorsunited-kingdom-uk/. Accessed 17 Dec 2018.

Bundesnetzagentur. (2004). Rufnummernmitnahme im Mobilfunk. Retrieved from: https://www. bundesnetzagentur.de/cln_1411/SharedDocs/Pressemitteilungen/DE/2004/041201Rufnummermobil.html. Accessed 17 Dec 2018.

Bundesregierung. (2011). Entwurf eines Gesetzes zur Änderung telekommunikationsrechtlicher Regelungen (BTDrs. 17/5707). Retrieved from: http://dipbt.bundestag.de/dip21/btd/17/057/1705707.pdf. Accessed 17 Dec 2018.

CBC News. (2012). CRTC gets earful on 3-year cell phone contracts. Retrieved from: http://www.cbc. ca/news/canada/crtc-gets-earful-on-3-year-cellphone-contracts-1.1142269. Accessed 17 Dec 2018.

CBC News. (2013). How your cellphone contract could change for the better. CBC Technology and Science. Retrieved from: http:/www.cbc.ca/news/technology/how-your-cellphone-contract-could-change-for-thebetter-1.1312770. Accessed 17 Dec 2018.

Chang, T. (2012). Analysis of various provisions in cell phone contracts. Fair Contracts Project. http://www. faircontracts.org/issues/cell-phones. Accessed 18 May 2019.

Chu, A. (2009). An analysis of the mobile wireless services industry in Canada (unpublished MBA thesis, Simon Fraser University). Retrieved from: http://summit.sfu.ca/system/files/iritems1/776/MBA\%202009\%20 Chu\%2C\%20A.pdf. Accessed 17 Dec 2018.

Cooter, R., \& Ulen, T. (2012). Law and economics. Boston, MA: Pearson.

Dodsworth, T. J. (2015). The underlying values of German and English contract law (unpublished PhD thesis, University of Warwick) (on file with author).

Dodsworth, T. J., Baltrusch, V. S., Dallemagne, U., \& Topf Aguiar de Medeiros, D. (2014). A comparative study of automatically renewable contracts in Europe. Business Law Review, 35, 93-100. 
FierceWireless. (2018). Wireless subscriptions market share by carrier in the U.S. from 1st quarter 2011 to $3 \mathrm{rd}$ quarter 2018. Statista. Retrieved from: https://www.statista.com/statistics/199359/market-share-of-wirelesscarriers-in-the-us-by-subscriptions/. Accessed 17 Dec 2018.

Fitchard, K. (2015). The cell phone contract era is so dead. Fortune Technology. Retrieved from: http://fortune. com/2015/08/10/cellphone-contract-era/. Accessed 17 Dec 2018.

Glenn, P. H. (2012). Comparative legal families and comparative legal traditions. In M. Reimann \& R. Zimmermann (Eds.), The Oxford handbook of comparative law (pp. 422-439). Oxford: Oxford University Press.

Horowitz, E. A. (2006). An analysis of change-of-terms provisions as used in consumer services contracts of adhesion. University of Miami Business Law Review, 15, 75-112.

Kenny, M. (2011). Orchestrating sub-prime consumer protection in retail banking: Abbey national in the context of Europeanised private law. European Review of Private Law, 19, 43-69.

Knapp, C. (2013). Unconscionability in American contract law. In L. A. DiMatteo, Q. Zhou, S. Saintier, \& K. Rowley (Eds.), Commercial contract law: Transatlantic perspectives (pp. 309-388). New York, NY: Cambridge University Press.

Leff, A. (1967). Unconscionability and the code: The emperor's new clause. University of Pennsylvania Law Review, 115(4), 485-559.

Legrand, P. (1997). The impossibility of "legal transplants". Maastricht Journal of European and Comparative Law, 4, 111-124.

Lunn, P. D. (2013). Telecommunications consumers: A behavioral economic analysis. Journal of Consumer Affairs, 47, 167-189.

Maissen, E. (2012). Die automatische Vertragsverlängerung. Zurich: Schulthess.

Malala, J. (2018). Consumer law and policy in Kenya. Journal of Consumer Policy, 41, 355-371.

Masse, P. \& Beaudry, P. (2014). The state of competition in Canada's telecommunications industry - 2014. Montreal Economic Institute. Retrieved from: http://www.iedm.org/files/cahier0214_en.pdf . Accessed 17 Dec 2018.

McKinsey. (2018). Thinking inside the subscription box: New research on e-commerce consumers. Retrieved from: https://www.mckinsey.com/industries/high-tech/our-insights/thinking-inside-the-subscription-boxnew-research-on-ecommerce-consumers\#0. Accessed 17 Dec 2019.

Middleton, C. (2011). Canada's telecommunication policy environment. Telecommunication Journal of Australia, 61, 69.1-69.14.

NGL Nordicity Group Ltd. (2017). 2017 price comparison study of telecommunications services in Canada and select foreign jurisdictions. Innovation, Science and Economic Development Canada (ISED). Retrieved from: https://www.ic.gc.ca/eic/site/693.nsf/vwapj/Nordicity2017EN.pdf/\$file/Nordicity2017EN.pdf. Accessed 17 Dec 2018.

Nielson Company. (2013). The mobile consumer - A global snapshot. Retrieved from: http://www.nielsen. com/content/dam/corporate/us/en/reports-downloads/2013\%20Reports/Mobile-Consumer-Report-2013.pdf. Accessed 17 Dec 2018.

O'Grady, P. D (2008) Laws and bills to protect cell phone customers. Illinois General Assembly Legislative Research Unit. Retrieved from: http:/www.ilga.gov/commission/lru/4.CellphoneLaws.pdf. Accessed 17 Dec 2018.

OECD. (2011). OECD communications outlook 2011. Organisation for Economic Co-operation and Development. Paris: OECD Publishing. Retrieved from: https://doi.org/10.1787/comms_outlook-2011-en. Accessed 17 Dec 2018.

OECD. (2013). OECD Communications Outlook 2013. Organisation for Economic Co-operation and Development. Paris: OECD Publishing. Retrieved from: https://www.oecd-ilibrary.org/science-andtechnology/oecd-communications-outlook-2013_comms_outlook-2013-en. Accessed 17 Dec 2018.

OECD. (2016). OECD economic surveys: Canada (June 2016). Retrieved from: https://www.oecd. org/eco/surveys/Canada-overview-OECD-economic-survey-2016.pdf. Accessed 17 Dec 2018.

Ofcom. (2011). Automatically renewable contracts: Research into their effects and proposals for a general condition. Retrieved from http://stakeholders.ofcom.org.uk/binaries/consultations/arcs/summary/arcs.pdf. Accessed 17 Dec 2018.

Ofcom. (2013a). The consumer experience of 2012. Retrieved from: https://www.ofcom.org.uk/ data/assets/pdf_file/0024/71907/consumer_experience_researc1.pdf. Accessed 17 Dec 2018.

Ofcom. (2013b). Guidance on "material detriment" under GC9.6 in relation to price rises and notification of contract modifications. Retrieved from http://stakeholders.ofcom.org.uk/binaries/consultations/gc9 /statement/guidance.pdf. Accessed 17 Dec 2018.

Ofcom. (2015a). Consolidated version of general conditions. Retrieved form: https://www.ofcom.org.uk/ data/assets/pdf_file/0026/86273/CONSOLIDATED_VERSION_OF_GENERAL_CONDITIONS_AS_ AT_28_MAY_2015-1.pdf. Accessed 17 Dec 2018. 
Ofcom. (2015b). Guidance on unfair terms in contracts for communication services. Retrieved from: https://www.ofcom.org.uk/_data/assets/pdf file/0012/40620/guidance.pdf. Accessed 17 Dec 2018.

Ofcom. (2018). Pricing trends for communications services in the UK. Retrieved from: https://www.ofcom.org. uk/_data/assets/pdf_file/0030/113898/pricing-report-2018.pdf. Accessed 17 Dec 2018.

Posner, E. A. (1995). Contract law in the welfare state: A defense of the unconscionability doctrine, usury Laws, and related limitations on the freedom to contract. The Journal of Legal Studies, 24, 283-319.

Public Utilities Commission of the State of California. (2006). Revised General Order 168, Market Rules to Empower the Telecommunications Consumers and to Prevent Fraud (Decisions 06/03/013). Retrieved from: http://docs.cpuc.ca.gov/word_pdf/GENERAL_ORDER/54500.pdf. Accessed 17 Dec 2018.

Rott, P. (2013). The adjustment of long-term supply contracts: Experience from German gas Price case law. European Review of Private Law, 21, 717-746.

Samuel, G. (2014). An introduction to comparative law theory. Oxford: Hart Publishing.

Standing Committee on Industry Science and Technology. (2010). Canada's foreign ownership rules and regulations in the telecommunications sector. Canada: Speaker of the House of Commons. Retrieved from http:/www.ourcommons.ca/Content/Committee/403/INDU/Reports/RP4618793/indurp05/indurp05-e.pdf. Accessed 17 Dec 2018.

Statistisches Bundesamt. (2017). Veränderung der Preise für Telekommunikationsdienstleistungen in Deutschland von 1996 bis 2017 (gegenüber dem Vorjahr). Retrieved from: https://de.statista. com/statistik/daten/studie/215848/umfrage/entwicklung-der-preise-fuer-telekommunikation-in-deutschland/. Accessed 17 Dec 2018.

Telecom Regulatory Policy 2013-271 (Canada).

Timetoast. (2015). History of cellphone prices. Retrieved form: http://www.timetoast.com/timelines/history-ofcellphones-prices. Acessed 17 Dec 2018.

VATM. (2018) Marktanteile der einzelnen Netzbetreiber an den Mobilfunkanschlüssen in Deutschland von 1998 bis 2018. Statista. Retrieved from: https://de.statista.com/statistik/daten/studie/3028/umfrage/marktanteileder-netzbetreiber-am-mobilfunkmarkt-in-deutschland-seit-1998/. Accessed 17 Dec 2018.

Wall Communications Inc. (2014). Price comparisons of wireline, wireless and internet Services in Canada and with foreign jurisdictions (2014 update). CRTC. Retrieved from: http://www.crtc.gc. ca/eng/publications/reports/rp140714.pdf. Accessed 17 Dec 2018.

Watkins, D. (2009). Terms subject to change: Assent and unconscionability in contracts that contemplate amendment. Cardozo Law Review, 31, 545-581.

Weir, T. (1992). Contracts in Rome and England. Tulane Law Review, 66, 1615-1648.

Zschieschack, F. (2018). § 307 BGB. In B. Gsell, W. Krüger, S. Lorenz \& F. Reymann (Eds.), Beck-OGK. München: Beck.

Zweigert, K., \& Kötz, H. (1998). Introduction to comparative law. Oxford: Oxford University Press.

Publisher's Note Springer Nature remains neutral with regard to jurisdictional claims in published maps and institutional affiliations. 